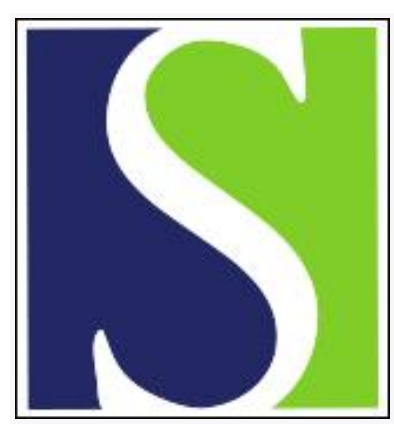

Scand J Work Environ Health 1999;25(1):5-17

https://doi.org/10.5271/sjweh.377

Issue date: Feb 1999

\title{
Lymphatic and hematopoietic cancer in teachers
}

by Baker P, Inskip H, Coggon D

Key terms: education; Hodgkin's disease; lymphoma; multiple myeloma; review; teacher

This article in PubMed: www.ncbi.nlm.nih.gov/pubmed/10204665

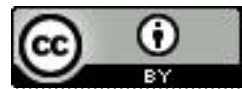




\title{
Lymphatic and hematopoietic cancer in teachers
}

\author{
by Paul Baker, MRCGP,' Hazel Inskip, PhD,' David Coggon, DM'
}

\begin{abstract}
Baker P, Inskip H, Coggon D. Lymphatic and hematopoietic cancer in teachers. Scand J Work Environ Health $1999 ; 25(1): 5-17$.

A recent study found high rates of leukemia and related disorders among teachers. This finding may be related to exposure to childhood infections. Therefore, epidemiologic studies on the risk of lymphatic and hematopoietic cancer among teachers were systematically reviewed. Altogether 26 relevant investigations were identified, most from ad hoc publications rather than from scientific journals. Elevated risks of leukemia, lymphoma, and multiple myeloma were found in studies using proportional mortality or mortality odds ratios as outcome measures. However, these observations may reflect low overall mortality and do not necessarily indicate high death rates from the cancers of interest. In studies deriving standardized mortality or incidence ratios, the risk estimates were generally lower. The most striking finding was for non-Hodgkin's lymphoma (approximate summary relative risk $1.36,95 \%$ confidence interval 1.13-1.62), but it was likely to have been exaggerated by publication bias. In conclusion, no compelling epidemiologic evidence exists for a hazard of leukemia or related diseases among teachers.
\end{abstract}

Key terms education, Hodgkin's disease, lymphoma, multiple myeloma, review, teachers.

A national analysis of occupational mortality in England and Wales during 1979-1980 and 1982-1990 indicated high rates of leukemia and related disorders among teachers (1). Teaching is not generally regarded as a hazardous occupation, and teachers' exposure to most of the known and suspected causes of lymphatic and hematopoietic cancer would not be expected to exceed that of the general population. Some science teachers in secondary schools and higher education work with ionizing radiation and benzene, but they are only a small minority of the profession as a whole, and their exposures are usually low. Potentially more relevant is the scope for contact with childhood infections during teaching.

At least 3 specific infections are known to cause lymphatic and hematopoietic cancer in humans. The human T-cell leukemia virus-1 (HTLV-1) has been linked with adult T-cell leukemia and lymphoma (2); Epstein-Barr virus contributes to the development of Burkitt's lymphoma and possibly Hodgkin's disease (2); and nonHodgkin's lymphoma is a recognized complication of acquired immunodeficiency syndrome (AIDS) caused by human immunodeficiency virus (HIV) $(3,4)$. Together, these infections only account for a small proportion of the leukemias and lymphomas that occur in western countries, but the observation that leukemia and Hodgkin's disease cluster geographically, without any obvious explanation in the local environment, suggests that other infections may also have a causal role. In support of this possibility, Kinlen et al $(5,6)$ have accumulated evidence that rates of leukemia in children are elevated in communities that have experienced a recent large influx of migrants, such as in "new" towns and around newly constructed industrial facilities in rural areas. They proposed that the high rate of leukemia results from the spread of one or more infections introduced by the immigration.

There is little direct evidence on the incidence of infections among teachers. In a survey in 1990, which collected information in an interview of a representative sample of 75000 adults in England and Wales, people working in education and welfare reported significantly raised rates of work-related infectious disease (7). This finding may simply reflect varying perceptions of what is work-related, rather than a true difference in risk.

Reprint requests to: Professor David Coggon, MRC Environmental Epidemiology Unit, Southampton General Hospital, Southampton, S0166YD, UK. [E-mail: DNC@mrc.soton.ac.uk] 
However, it is plausible that teachers have a high incidence of occupationally acquired infections and that these infections may constitute a hazard for leukemia and lymphoma. We therefore undertook a systematic review of the epidemiologic evidence on the risk of lymphatic and hematopoietic cancer among teachers.

\section{Methods}

We searched for relevant publications in 3 computerized data bases (MEDLINE from 1966, HSELINE from 1977 and BIDS EMBASE from 1980), using the key terms leukaemia/leukemia, lymphoma, myeloma, multiple - my eloma, myelofibrosis, polycythaemia/polycythemia vera, and anaemia/anemia - aplastic in combination with any of teaching, teacher(s), lecturer(s), and occupational. The references were first evaluated on the basis of their full titles and abstracts if available. They were then selected for detailed review if it appeared that they might include relevant data. Apart from the British Registrar General's decennial supplements on occupational mortality, no studies were identified through HSELINE or BIDS that were not also identified from MEDLINE.

In addition we consulted Dr Paolo Boffetta at the International Agency for Research on Cancer, who drew to our attention 6 large analyses of occupational mortality or cancer incidence that had not emerged from the computer search, and we also contacted the UK Health and Safety Executive, which identified a further 13 potentially relevant publications, principally through a search of NIOSHTIC. One other study was discovered secondarily, having been referenced in reports identified by the primary search.

Approximate summary estimates of relative risk were derived by summing observed and expected numbers of cases across studies. If expected numbers were not published, they were calculated as the ratio of observed cases to whatever measure of relative risk had been used. Confidence intervals for the summary estimates were based on the Poisson distribution.

\section{Results}

The following studies provided information about the risk of leukemia and related diseases among teachers.

\section{Occupational mortality in England and Wales, 1949- 1953}

Approximately every 10 years, the Registrar General publishes national statistics on occupational mortality in England and Wales. An analysis for the years
1949-1953 focused on deaths among men aged $20-64$ years and obtained information from death certificates about the last occupation of decedents and their underlying causes of death (8). Estimates of the population at risk in each occupation were based on the 1951 census and were used to calculate standardized mortality ratios (SMR) by occupation and cause, with age-specific death rates in the national population as the standard. Teachers had an SMR of 0.83 for leukemia based on 19 observed deaths.

\section{Occupational mortality in England and Wales, 1959- 1963}

The next report in this series covered the 5 years centered on the 1961 census, and used a similar method except that it included deaths of people between 15 and 64 years of age, and it looked at single women as well as at men (9). The SMR for leukemia in nonuniversity teachers was 1.02 for men (based on 41 deaths) and 1.08 for women (26 deaths). The corresponding SMR for male university teachers was 1.50 (based on 3 deaths).

\section{Occupational mortality in England and Wales, 1970- 1972}

A further analysis, based on the 1971 census, included deaths from only 3 years (1970-1972), but, as well as calculating the SMR for people of working age, the authors also derived proportional mortality ratios (PMR) for men aged $65-74$ years and women aged $60-74$ years (with age-specific proportions in the national population as the standard) (10). Among primary and secondary teachers, mortality from lymphoma was consistently elevated for the men, while for single women the death rates from leukemia were higher than expected. None of the associations was statistically significant, however.

\section{Occupational mortality in Great Britain, 1979-1980 and 1982-1983}

The next analysis centered on the 1981 census and included Scotland, as well as England and Wales (11). However, deaths during the central year of the study period (1979-1983) were excluded because industrial action in that year by Registry Office staff rendered the information from death certificates unreliable. The SMR for leukemia among nonuniversity teachers aged $20-64$ years was somewhat elevated, the excess of deaths being from myeloid leukemia and especially chronic myeloid leukemia (SMR 1.46, 13 deaths).

\section{Occupational mortality in England and Wales, 1979- 1980 and $1982-1990$}

The most recent analysis in this series was the one that prompted our review. (1) It partially overlapped with the analysis based on the 1981 census (11), covering deaths at ages $20-74$ years during $1979-1980$ and 
1982 - 1990, but excluding Scotland. As appropriate data on populations at risk were unavailable, only PMR values could be calculated. The PMR values were significantly elevated for acute lymphatic leukemia, chronic lymphatic leukemia, acute myeloid leukemia, chronic myeloid leukemia, Hodgkin's disease, non-Hodgkin's lymphoma, multiple myeloma, aplastic anemia, and agranulocytosis in male nonuniversity teachers; for acute myeloid leukemia, Hodgkin's disease, non-Hodgkin's lymphoma and multiple myeloma in female nonuniversity teachers; and for chronic lymphatic leukemia, acute myeloid leukemia, chronic myeloid leukemia, non-Hodgkin's lymphoma and multiple myeloma in male teachers in higher education.

\section{Cancer incidence in England and Wales 1966-1967 and 1968-1969}

The Registrar General's decennial supplement on occupational mortality in England and Wales during 19701972 also included limited information on cancer registrations by occupation during 1966-1967 and 19681969 (10). Data were presented for occupations and cancers where the male proportional registration ratio (PRR) at ages $15-74$ years was significantly elevated $(\mathrm{P}<0.01)$ for either of these periods. None of the PRR values for leukemia or lymphoma in teachers satisfied this criterion.

\section{Cancer incidence in England, 1981-1987}

A larger analysis of cancer incidence by occupation was carried out using data from registrations for men and women aged 20-74 years in England during 19811987 (12). Valid occupational codes were available for $36 \%$ of the 1034759 registrations over this period. PRR values were published when significantly (at a $5 \%$ level) elevated and based on 3 or more observed cases. None of the lymphatic or hematopoietic cancers met this requirement for teachers in higher education, but the PRR values for chronic myeloid leukemia ( 1.55 based on 25 registrations) and myeloma (1.44 based on 60 registrations) were high for nonuniversity male teachers. Some of the cases may have been the same as those contributing to the raised PMR values for these diseases during 1979-1980 and 1982-1990.

\section{Occupational mortality in the United States, 1950}

An analysis of mortality by occupation in the United States (US) was carried out using data on deaths among men aged 20-64 years in 1950 (13). Information about the cause of death and occupation of decedents was obtained from death certificates, and the SMR values were calculated with populations at risk derived from the 1950 national census. There were 10 deaths from lymphatic and hematopoietic cancers among college presidents, professors and instructors and 31 among teachers, but the
SMR values were not published for these combinations of occupation and cause of death.

\section{Occupational mortality in Washington State, 1950- 1989}

Milham analyzed all deaths among white males aged 20-64 years in Washington State in the United States during 1950-1989 and all deaths among white females aged 20-64 years during 1974-1989 (14). The age at death, underlying cause of death, and usual occupation of the deceased subjects were ascertained from death certificates and were used to derive age-standardized PMR values by occupation and cause of death with the annual proportions in the total sample as the standard. The PMR values for lymphatic and hematopoietic cancers in male and female school teachers and male professors and instructors were generally elevated.

This study overlapped an earlier proportional mortality analysis for male residents of Washington State aged 20 years or over, covering the period $1950-1971$. In this earlier analysis, described in a letter to the New England Journal of Medicine, teachers had a PMR of 2.46 for Hodgkin's disease based on 12 deaths (15).

\section{Occupational mortality in California, 1959-1961}

An analysis of occupational mortality similar to those for Washington State was carried out for white males aged 20 years and older in the state of California during 1959-1961 (16). Professors and instructors had excess mortality from multiple myeloma, and teachers from Hodgkin's disease and non-Hodgkin's lymphoma, but none of these associations was statistically significant.

\section{Mortality by occupation among veterans in the United States}

In this study, approximately 250000 veterans who had served in the US forces during 1917-1940 completed baseline questionnaires in 1954 or 1957 about their occupation and smoking habits (response rate 84\%) (17). They were subsequently followed to 1980 through life insurance claims and records of the Veterans' Association, and the mortality of white males in specified occupations was compared with that of all other occupations combined by Poisson regression analysis. The records of death were thought to be $96 \%$ complete. Estimates of relative risk (RR) were presented separately for ever and never smokers.

The relative risks for lymphatic and hematopoietic cancer in teachers were all close to or less than 1 , the highest (1.2) being for malignant lymphoma and for multiple myeloma in smokers. However, these values were not statistically significant.

\section{Occupational mortality from cancer in Massachusetts}

Mortality from cancer by occupation was analyzed for the state of Massachusetts using data from death 
certificates of white males aged 20 years or older who died in 1971-1973 (18). Age-standardized mortality odds ratios (MOR) were calculated by occupation for specified cancers, with all noncancer deaths (other than from cirrhosis) as reference. Significantly elevated odds ratios were reported for malignant lymphoma in college and university teachers and administrators ( 5.77 based on 6 deaths), and for multiple myeloma in school professions (2.97 based on 5 deaths). Only findings that were significant at a $5 \%$ level were presented.

\section{Leukemia incidence in the Portland-Vancouver metropolitan area, 1963-1977}

Cases of leukemia among residents between the ages of 16 and 74 years in the Portland-Vancouver metropolitan area during 1963-1977 were identified by a search of the records of all 24 hospitals in the area (tumor registration data, diagnostic indices and pathology reports), and by a review of death certificates mentioning leukemia (19). Diagnostic information, demographic details, and usual occupation were obtained from hospital records and used to derive directly standardized incidence rates by occupation up to the age of 67 years, with the 1970 US population as the standard. The populations at risk in each occupation were obtained from the 1970 census. Risk of leukemia was significantly elevated for both male and female school teachers.

\section{Mortality by occupation, industry, and cause of death in 24 states in the United States, 1984-1988}

Occupational mortality was analyzed for men and women aged 20 years and older (other than housewives and homemakers) in 24 states in the United States during 1984-1988 (20). Information about underlying cause of death and usual occupation was obtained from death certificates, and age-standardized PMR values were derived with the proportions from all occupations combined as the standard. The PMR values are presented in the published report where they were 1.2 or higher, statistically significant, and based on 10 or more deaths. Such excesses were found for leukemia in male and female school teachers and male postsecondary teachers, nonHodgkin's lymphoma and multiple myeloma in male school teachers and postsecondary teachers, and multiple myeloma in female school teachers.

\section{Mortality from non-Hodgkin's lymphoma by occupation in 24 states in the United States, 1984- 1989}

In an analysis which overlapped with that already described, men and women who died from non-Hodgkin's lymphoma in the same 24 states in the United States during 1984-1989 were identified from death certificates and compared with referents ( 5 per case, frequency matched for age, gender and race) who died of causes other than cancer (21). Information about each subject's occupation was obtained from his or her death certificate, and MOR values were calculated for specified occupations in comparison with all other occupations combined by logistic regression.

In the published report of this analysis, the results were only presented for associations that were statistically significant at a $5 \%$ level, or based on 5 or more deaths in the relevant occupation with an odds ratio of 2 or higher. Such associations were found for several categories of teachers, including white male and female elementary and secondary teachers and black female elementary teachers.

\section{Mortality from multiple myeloma by occupation in 24} states in the United States, 1984-1989

This study (22) looked at occupational associations with myeloma using a method similar to that employed in the investigation of non-Hodgkin's lymphoma already described. Again, it overlapped the PMR analysis for $1984-1988$, and the results were only presented for associations based on 5 or more deaths with an odds ratio of 2 or higher or that were statistically significant at a $5 \%$ level. Occupational groups for which these criteria were satisfied included white male, white female, and black female elementary teachers and black female postsecondary teachers.

\section{Mortality of teachers in New Jersey, 1980-1984}

This analysis was based on deaths during 1980-1984 among members of the New Jersey Teachers' Pension Fund (23). The membership of the fund included all active teachers, all who had retired after at least 25 years of service, and some who had worked in teaching for a shorter time but had had at least 10 years of teaching. Underlying causes of death were ascertained from death certificates, and proportional mortality ratios were calculated by cause of death with 2 alternative sets of gender-, age- and race-specific proportions as standards from the national population and from the state of New Jersey.

The results with the 2 standards were broadly similar. The PMR values were significantly elevated for lymphatic and hematopoietic cancer overall among white women and specifically for Hodgkin's disease among white women. However, no corresponding excesses were observed for white men or black teachers. Proportional cancer mortality ratios (PCMR) were also calculated, and in each case they were somewhat lower than the corresponding PMR values.

\section{Mortality of teachers in Pennsylvania, 1983-1984}

Age-standardized PMR values were calculated for primary and secondary school teachers in Pennsylvania using information on occupation and cause of death from 
death certificates of people who died during 1983-1984 (24). Findings were reported in which, for one or more strata of race and gender, there were at least 3 observed deaths and a PMR of $>1.00$, or the PMR was significantly elevated at a $5 \%$ level. Mortality from leukemia and Hodgkin's disease was largely unremarkable, but excesses of deaths were found for multiple myeloma among white women, and for non-Hodgkin's lymphoma among white men.

\section{Hodgkin's disease and occupation in Boston, 1959 1973}

Cases of Hodgkin's disease occurring in residents of Boston during 1959-1973 were sought from the records of 74 out of 76 local nonpsychiatric hospitals (25). A search was made of diagnostic indices, tumor registry files, pathology reports, and radiotherapy records. Information about the cases' occupations at the time of diagnosis was obtained from the medical records, and ratios of observed to expected cases (standardized incidence ratios, SIR) by occupation were calculated, the expected numbers being based on average population data from the 1960 and 1970 censuses and the overall age- and gender-specific incidence rates of the study population. The incidence for teachers was close to expectation [SIR 1,1,95\% confidence interval (95\%CI) $0.7-1.6]$.

\section{Cancer incidence by occupation in Denmark, 1970- 1979}

In this investigation, cases of cancer in the Danish population during 1970-1979 were identified from the Danish Cancer Register, and their occupational histories during 1964-1979 were obtained by record linkage with national pension fund records and the central population register (26). Age-standardized proportional incidence ratios (SPIR) were calculated according to the industry in which the subjects had worked the longest with the annual age-specific proportions of the total study population as the standard.

The results were not reported for teachers as such, but findings were given for employment in educational services. A small excess of cases was observed for nonacute leukemia in women, but this excess was not statistically significant. Otherwise, the numbers of cases were close to or below expectation. It is estimated that among those working in educational services, approximately $90 \%$ of the men and $57 \%$ of the women would have been teachers (Hansen J, personal communication).

\section{Mortality by occupation in Turin, 1981-1989}

Residents of Turin were identified from the 1981 census with information about their occupation at the time of the census (27). The cohort was then followed for mortality to the end of 1989 through the municipal death register. Follow-up for the subjects who left Turin during the study period (17.6\% of the total) was censored at the time of migration. Causes of death were ascertained from death certificates, and SMR values were calculated for specified occupational groups in comparison with the whole active population. (Information about the cause of death was missing for $4.5 \%$ of the deaths.) There were only small numbers of deaths from lymphatic and hematopoietic cancer among teachers, and no clear increases in risk were observed.

\section{Occupational mortality in Italy, 1981-1982}

This analysis focused on Italian residents between the ages of 18 and 74 years. The subjects were identified from the 1981 census with information about their occupation and were followed for mortality over the next 6 months through death registers (27). Some $16 \%$ of the deaths could not be linked with census records and were excluded from the analysis. Age-adjusted odds ratios were calculated for specified occupational groups and causes of death using all other causes of death as the control and all other occupations combined as the comparator. For teachers and professors most of the odds ratios for lymphatic and hematopoietic cancer were elevated, several to the point of statistical significance.

\section{Cancer incidence in Finland by occupation, 1971- 1985}

Registrations of people of work age in 1971-1985 at the Finnish Cancer Registry were linked with information about their current occupations from the 1970 census (28). Risks of specified cancers were estimated by occupation and were characterized by SIR values with expected numbers based on the incidence for the total economically active Finnish population of the same gender, 5-year age group, and social class during each 5-year period of follow-up.

The results were reported for combinations of occupation and cancer with at least 5 cases expected or an SIR significantly different from the null. Small excesses were observed for non-Hodgkin's lymphoma among male teachers overall, and for multiple myeloma in female school teachers, but neither was statistically significant.

\section{Cancer mortality by occupation in Switzerland}

This analysis of cancer mortality by occupation among Swiss men aged 30 years or older who died during 1979-1982 used information on occupation and cause of death from death certificates (29). SMR values were calculated using information about the occupational populations at risk from the 1980 census, and PMR values were also derived. Results were only published for occupations with a significantly raised or lowered SMR or PMR for the cancers studied, and such an increase did not occur for leukemia or lymphoma in teachers. 


\section{Non-Hodgkin's lymphoma and occupation in Sweden}

This study linked data on occupation for Swedish men from the 1960 census with cancer registrations during 1961 - 1979 and calculated standardized cumulative incidence ratios for non-Hodgkin's lymphoma in each occupation, with expected numbers of cases based on 5year birth cohort, gender, and region-specific rates for the general population (30). The incidence of non-Hodgkin's lymphoma was significantly elevated both for school teachers (14 cases, SIR 2.1, 95\% CI 1.2-3.5) and for special teachers ( 24 cases, SIR $1.6,95 \%$ CI $1.0-2.4$ ).

\section{Occupational mortality in British Columbia, 1950- 1984}

A proportional mortality analysis was carried out based on deaths among men and women aged 20 years and older in British Columbia during 1950-1984 (31). Information about age at death, underlying cause of death, and occupation was obtained from death certificates. The PMR for leukemia was significantly elevated for male teachers $(1.75,95 \%$ CI $1.16-2.53)$.

The findings from these studies for all leukemia, lymphatic leukemia, nonlymphatic leukemia, Hodgkin's disease, non-Hodgkin's lymphoma, and multiple myeloma are set out in more detail in tables 1 to 6 . The tables also show approximate summary estimates of risk for the combination of all categories of teacher [including work in educational services in Denmark (26)], all age groups, and both genders. These estimates were derived separately for the studies based on incidence or mortality rates and those that analyzed proportional mortality, mortality odds ratios, or proportional cancer incidence. For all the disease categories examined, the summary estimates of relative risk derived from proportional analyses were significantly elevated. However, those based on incidence or mortality rates were generally lower and close to unity. The 2 exceptions were lymphatic leukemia (RR $1.77,95 \% \mathrm{CI} 1.22-2.47)$ and non-Hodgkin's lymphoma (RR $1.36,95 \%$ CI $1.13-1.62)$.

\section{Discussion}

When the assembled evidence is interpreted, several limitations must be taken into consideration.

\section{Completeness of literature search}

We attempted to identify all published studies that provide epidemiologic data relevant to the risk of leukemia and related disorders in teachers, but our search may not have been comprehensive. Many data were available only from government reports, and these were not always included in the computerized data bases that we were able to search. Moreover, some pertinent studies that were included in the data bases may have been missed because they did not register under the index terms that we used. To minimize the risk of such omissions we kept our initial search broad, and, although several relevant publications were only ascertained from a single source, we think major underascertainment is unlikely.

\section{Completeness of published data}

A related concern is the completeness with which relevant data have been published. Leukemia and lymphoma are rare diseases, and findings based on small numbers of cases may have escaped publication, particularly if the associated risk estimate was unremarkable. Such a problem occurred, for example, in the Registrar General's analysis of cancer incidence in England during 1981-1987 (12), from which PRR values for hematopoietic cancer among teachers were only published if they were significantly elevated at a $5 \%$ level and based on three or more observed cases. In general, the effect of such underreporting will be a bias towards more positive estimates of risk.

\section{Completeness and reliability of occupational information}

Most of the studies reviewed used occupational information from death certificates or census returns, which normally allow for a record of only 1 occupation. Where people have changed jobs over the course of their career, an occupation that contributed to their death would not necessarily be the one that was registered. In addition, the occupations recorded on death certificates are not always accurate or specific.

In general, the effect of such errors will be to bias risk estimates towards unity, but spurious associations may be generated in SMR analyses in which the occupational information for the numerator and denominator of rates is derived from 2 different sources. Bias of this type has been well documented for certain occupations (32), but is less likely to apply to a profession such as teaching, which is familiar to most people and should not be difficult to report accurately.

\section{Accuracy and specificity of diagnoses}

A few of the studies reviewed used clinical records to confirm diagnoses, but most relied on diagnoses obtained from cancer registrations or death certificates. The latter, in particular, are known to be subject to error, which, if nondifferential with respect to occupation would tend to obscure associations with work. Errors in diagnosis are especially likely to occur when more specific diagnostic classifications are employed. For example, there may be 
Table 1. Summary of findings for leukemia. a $(\mathrm{RR}=$ relative risk, $95 \% \mathrm{Cl}=95 \%$ confidence interval, $\mathrm{SMR}=$ standardized mortality ratio, $\mathrm{PMR}=$ proportional mortality ratio, $\mathrm{MOR}=$ mortality odds ratio, $\mathrm{SIR}=$ standardized incidence ratio, $\mathrm{SPIR}=$ standardized proportional incidende ratio)

\begin{tabular}{|c|c|c|c|c|c|c|c|c|c|}
\hline Reference & Place & Period & Occupation & $\begin{array}{c}\text { Age } \\
\text { (years) }\end{array}$ & Gender & $\begin{array}{l}\text { Number } \\
\text { of cases }\end{array}$ & $\begin{array}{l}\text { Measure } \\
\text { of risk }\end{array}$ & $R R$ & $95 \% \mathrm{Cl}$ \\
\hline $\begin{array}{l}\text { egistrar General, } \\
958 \text { (8) }\end{array}$ & England and Wales & $49-1953$ & hers & $20-64$ & Male & 19 & SMR & 0.83 & $0.50-1.29^{b}$ \\
\hline $\begin{array}{l}\text { egistrar General, } \\
971 \text { (9) }\end{array}$ & $\mathrm{d}$ and Wales & $959-1963$ & $\begin{array}{l}\text { Nonuniversity teachers } \\
\text { Nonumiversity teachers } \\
\text { University teachers }\end{array}$ & $\begin{array}{l}15-64 \\
15-59 \\
15-64\end{array}$ & $\begin{array}{l}\text { Male } \\
\text { Female }^{c} \\
\text { Male }\end{array}$ & $\begin{array}{r}41 \\
26 \\
3\end{array}$ & $\begin{array}{l}\text { SMR } \\
\text { SMR } \\
\text { SMR }\end{array}$ & $\begin{array}{l}1.02 \\
1.08 \\
1.50\end{array}$ & $\begin{array}{l}0.73-1.38^{b} \\
0.71-1.58^{b} \\
0.31-4.38^{b}\end{array}$ \\
\hline $\begin{array}{l}\text { Office of Population } \\
\text { Censuses and } \\
\text { Surveys, } 1978(10)\end{array}$ & England and Wales & $1970-1972$ & $\begin{array}{l}\text { Primary and secondary teachers } \\
\text { Primary and secondary teachers } \\
\text { Primary and secondary teachers } \\
\text { Primary and secondary teachers } \\
\text { University teachers } \\
\text { University teachers } \\
\text { University teachers } \\
\text { University teachers } \\
\text { Other teachers } \\
\text { Other teachers } \\
\text { Other teachers } \\
\text { Other teachers }\end{array}$ & $\begin{array}{l}15-64 \\
65-74 \\
15-59 \\
60-74 \\
15-64 \\
65-74 \\
15-59 \\
60-74 \\
15-64 \\
65-74 \\
15-59 \\
60-74\end{array}$ & $\begin{array}{l}\text { Male } \\
\text { Male } \\
\text { Female }^{c} \\
\text { Female }^{c} \\
\text { Male } \\
\text { Male } \\
\text { Female }^{c} \\
\text { Female }^{c} \\
\text { Male } \\
\text { Male } \\
\text { Female }^{c} \\
\text { Female }^{c}\end{array}$ & $\begin{array}{r}16 \\
8 \\
14 \\
10 \\
2 \\
2 \\
- \\
- \\
12 \\
4 \\
1 \\
3\end{array}$ & $\begin{array}{l}\text { SMR } \\
\text { PMR } \\
\text { SMR } \\
\text { PMR } \\
\text { SMR } \\
\text { PMR } \\
\text { SMR } \\
\text { PMR } \\
\text { SMR } \\
\text { PMR } \\
\text { SMR } \\
\text { PMR }\end{array}$ & $\begin{array}{r}0.75 \\
1.26 \\
1.49 \\
1.76 \\
0.89 \\
4.39 \\
0 \\
0 \\
0.97 \\
1.88 \\
0.46 \\
2.38\end{array}$ & $\begin{array}{c}0.43-1.22^{\mathrm{b}} \\
0.54-2.48^{\mathrm{b}} \\
0.82-2.50^{\mathrm{d}} \\
0.84-3.24^{\mathrm{b}} \\
0.11-3.21^{\mathrm{b}} \\
0.53-15.9^{\mathrm{b}} \\
\cdot . \\
\cdot . \\
0.50-1.69^{\mathrm{b}} \\
0.51-4.81^{\mathrm{b}} \\
0.01-2.56^{\mathrm{b}} \\
0.49-6.96^{\mathrm{b}}\end{array}$ \\
\hline $\begin{array}{l}\text { Office of Population } \\
\text { Censuses and } \\
\text { Surveys, } 1986(11)\end{array}$ & Great & $\begin{array}{l}1979-1980 \& \\
1982-1983\end{array}$ & $\begin{array}{l}\text { ty teachers } \\
\text { higher education }\end{array}$ & $\begin{array}{l}20-64 \\
20-64\end{array}$ & $\begin{array}{l}\text { Male } \\
\text { Male }\end{array}$ & $\begin{array}{l}48 \\
16\end{array}$ & $\begin{array}{l}\text { SMR } \\
\text { SMR }\end{array}$ & $\begin{array}{l}1.19 \\
1.04\end{array}$ & $\begin{array}{l}0.88-1.58^{\mathrm{b}} \\
0.59-1.69^{\mathrm{b}}\end{array}$ \\
\hline $\begin{array}{l}\text { Coggon et al, } \\
1995(1)\end{array}$ & England and Wales & $\begin{array}{l}1979-1980 \& \\
1982-1990\end{array}$ & $\begin{array}{l}\text { Nonuniversity teachers } \\
\text { Nonuniversity teachers } \\
\text { Teachers in higher education } \\
\text { Teachers in higher education }\end{array}$ & $\begin{array}{l}20-74 \\
20-74 \\
20-74 \\
20-74\end{array}$ & $\begin{array}{l}\text { Male } \\
\text { Female } \\
\text { Male } \\
\text { Female }\end{array}$ & $\begin{array}{r}184 \\
186 \\
66 \\
17\end{array}$ & $\begin{array}{l}\text { PMR } \\
\text { PMR } \\
\text { PMR } \\
\text { PMR }\end{array}$ & $\begin{array}{l}1.57^{\mathrm{b}} \\
1.36^{\mathrm{b}} \\
2.00^{\mathrm{b}} \\
1.93^{\mathrm{b}}\end{array}$ & $\begin{array}{l}1.35-1.81^{\mathrm{b}} \\
1.17-1.57^{\mathrm{b}} \\
1.54-2.54^{\mathrm{b}} \\
1.12-3.09^{\mathrm{b}}\end{array}$ \\
\hline Milham, 1997 (14) & Washington State & $\begin{array}{l}1950-1989 \\
1974-1989\end{array}$ & $\begin{array}{l}\text { School teachers } \\
\text { Professors and instructors } \\
\text { School teachers }\end{array}$ & $\begin{array}{l}20-64 \\
20-64 \\
20-64\end{array}$ & $\begin{array}{l}\text { Male } \\
\text { Male } \\
\text { Female }\end{array}$ & $\begin{array}{r}35 \\
7 \\
20\end{array}$ & $\begin{array}{l}\text { PMR } \\
\text { PMR } \\
\text { PMR }\end{array}$ & $\begin{array}{l}2.02 \\
1.54 \\
1.40\end{array}$ & $\begin{array}{l}1.41-2.81^{\mathrm{b}} \\
0.62-3.17^{\mathrm{b}} \\
0.86-2.16^{\mathrm{b}}\end{array}$ \\
\hline $\begin{array}{l}\text { Petersen \& Milham, } \\
1980(16)\end{array}$ & Califor & $\begin{array}{l}1959-1961 \\
1959-1961\end{array}$ & $\begin{array}{l}\text { Teachers } \\
\text { Professors and instructors }\end{array}$ & $\begin{array}{l}\geq 20 \\
\geq 20\end{array}$ & $\begin{array}{l}\text { Male } \\
\text { Male }\end{array}$ & $\begin{array}{l}5 \\
5\end{array}$ & $\begin{array}{l}\text { PMR } \\
\text { PMR }\end{array}$ & $\begin{array}{l}0.77 \\
1.14\end{array}$ & $\begin{array}{l}0.25-1.80^{\mathrm{b}} \\
0.37-2.66^{\mathrm{b}}\end{array}$ \\
\hline $\begin{array}{l}\text { Hrubec et al, } \\
1992(17)\end{array}$ & $\begin{array}{l}\text { United States } \\
\text { (veterans) }\end{array}$ & $1954-1980$ & $\begin{array}{l}\text { Teachers (nonsmokers) } \\
\text { Teachers (smokers) }\end{array}$ & $\begin{array}{l}\text { All } \\
\text { All }\end{array}$ & $\begin{array}{l}\text { Male } \\
\text { Male }\end{array}$ & $\begin{array}{l}16 \\
10\end{array}$ & $\begin{array}{l}\mathrm{RR} \\
\mathrm{RR}\end{array}$ & $\begin{array}{l}1.1 \\
1.0\end{array}$ & $\begin{array}{l}0.6-1.7^{b} \\
0.5-1.9^{b}\end{array}$ \\
\hline $\begin{array}{l}\text { Morton \& } \\
\text { Marjanovic, } \\
1984(19)\end{array}$ & Portland-Vancouver & $1963-$ & $\begin{array}{l}\text { School teachers } \\
\text { School teachers } \\
\text { College professors } \\
\text { College professors }\end{array}$ & $\begin{array}{l}16-74 \\
16-74 \\
16-74 \\
16-74\end{array}$ & $\begin{array}{l}\text { Male } \\
\text { Female } \\
\text { Male } \\
\text { Female }\end{array}$ & $\begin{array}{r}10 \\
13 \\
- \\
2\end{array}$ & $\begin{array}{l}R R \\
R R \\
R R \\
R R\end{array}$ & $\begin{array}{l}2.1^{\mathrm{b}} \\
1.7^{\mathrm{b}} \\
0 \\
2.9^{\mathrm{b}}\end{array}$ & $\begin{array}{l}. . \\
. . \\
. . \\
. .\end{array}$ \\
\hline $\begin{array}{l}\text { Burnett et al, } \\
1997(20)\end{array}$ & $\begin{array}{l}\text { United } \\
(24 \mathrm{~s}\end{array}$ & $1984-1988$ & $\begin{array}{l}\text { Teachers except postsecondary } \\
\text { Teachers except postsecondary } \\
\text { Teachers postsecondaryd }\end{array}$ & $\begin{array}{l}\geq 20 \\
\geq 20 \\
\geq 20\end{array}$ & $\begin{array}{l}\text { Male } \\
\text { Female } \\
\text { Male }\end{array}$ & $\begin{array}{r}105 \\
421 \\
36\end{array}$ & $\begin{array}{l}\text { PMR } \\
\text { PMR } \\
\text { PMR }\end{array}$ & $\begin{array}{l}1.32 \\
1.31 \\
1.53\end{array}$ & $\begin{array}{l}1.08-1.59 \\
1.19-1.44 \\
1.07-2.12\end{array}$ \\
\hline Dewar, 1986 (24) & Pennsylvania & $1983-1984$ & Primary and secondary teachers ${ }^{d}$ & All & Female & 32 & PMR & $1.26^{\mathrm{b}}$ & $0.86-1.78^{b}$ \\
\hline $\begin{array}{l}\text { Olsen \& Jensen, } \\
1987 \text { (26) }\end{array}$ & Denmark & $1970-1979$ & Educational services & $18-66$ & Male & 19 & SPIR & $0.90^{b}$ & $0.54-1.41^{b}$ \\
\hline Roseo, 1995 (27) & Turin & $1981-1989$ & $\begin{array}{l}\text { Teachers and professors } \\
\text { Teachers and professors }\end{array}$ & $\begin{array}{l}\text { All } \\
\text { All }\end{array}$ & $\begin{array}{l}\text { Male } \\
\text { Female }\end{array}$ & $\begin{array}{l}3 \\
4\end{array}$ & $\begin{array}{l}\text { SMR } \\
\text { SMR }\end{array}$ & $\begin{array}{l}1.47 \\
0.94\end{array}$ & $\begin{array}{l}0.30-4.30^{b} \\
0.26-2.41^{b}\end{array}$ \\
\hline Roseo, $1995(27)$ & Italy & $1981-1982$ & $\begin{array}{l}\text { Teachers and professors } \\
\text { Teachers and professors }\end{array}$ & $\begin{array}{l}18-64 \\
18-64\end{array}$ & $\begin{array}{l}\text { Male } \\
\text { Female }\end{array}$ & $\begin{array}{l}1 \\
9\end{array}$ & $\begin{array}{l}\text { MOR } \\
\text { MOR }\end{array}$ & $\begin{array}{l}0.33 \\
1.83\end{array}$ & $\begin{array}{l}. . \\
. .\end{array}$ \\
\hline Pukkala, 1995 (28) & Finland & $1971-1985$ & $\begin{array}{l}\text { All teachers } \\
\text { All teachers }\end{array}$ & $\begin{array}{l}35-64 \\
35-64\end{array}$ & $\begin{array}{l}\text { Male } \\
\text { Female }\end{array}$ & $\begin{array}{l}19 \\
18\end{array}$ & $\begin{array}{l}\text { SIR } \\
\text { SIR }\end{array}$ & $\begin{array}{l}0.85 \\
0.99\end{array}$ & $\begin{array}{l}0.51-1.33 \\
0.59-1.56\end{array}$ \\
\hline King, 1994 (31) & British Columbia & $1950-1984$ & $\begin{array}{l}\text { School teachers } \\
\text { School teachers }\end{array}$ & $\begin{array}{l}\geq 20 \\
\geq 20\end{array}$ & $\begin{array}{l}\text { Male } \\
\text { Female }\end{array}$ & $\begin{array}{l}28 \\
22\end{array}$ & $\begin{array}{l}\text { PMR } \\
\text { PMR }\end{array}$ & $\begin{array}{l}1.75 \\
1.11\end{array}$ & $\begin{array}{l}1.16-2.53 \\
0.69-1.68\end{array}$ \\
\hline
\end{tabular}

approximate summary estimates of relative risk: studies based on incidence or mortality rates: number of cases $293, \mathrm{RR} 1.06,95 \% \mathrm{Cl} 0.94-1.19$; tudies based on proportional mortality, mortality odds ratios or proportional cancer incidence; number of cases $1225, \mathrm{RR} 1.40,95 \% \mathrm{Cl} 1.33-1.48$. Calculated by us.

Single women only.

$\checkmark$ Whites only.

no doubt that a patient had leukemia, but the exact subtype of leukemia may be uncertain.

\section{Measures of relative risk}

Various measures of relative risk have been used in the reviewed studies according to their design. An important distinction must be made between those that directly compared rates of disease or mortality for teachers with those of other occupations or the general population and those that estimated risk from proportional incidence or mortality or from mortality odds ratios. Risk estimates in the latter category are influenced not only by the frequency of leukemia and related diseases among teachers, but also by their susceptibility to other diseases. 
Table 2. Summary of findings for lymphatic leukemia. ${ }^{a} \quad(R R=$ relative risk, $95 \% \mathrm{Cl}=95 \%$ confidence interval, $\mathrm{SMR}=$ standardized mortality ratio, $\mathrm{PMR}=$ proportional mortality ratio)

\begin{tabular}{|c|c|c|c|c|c|c|c|c|c|}
\hline Reference & Place & Period & Occupation & $\begin{array}{c}\text { Age } \\
\text { (years) }\end{array}$ & Gender & $\begin{array}{l}\text { Number } \\
\text { of cases }\end{array}$ & $\begin{array}{l}\text { Measure } \\
\text { of risk }\end{array}$ & $R R$ & $95 \% \mathrm{Cl}$ \\
\hline $\begin{array}{l}\text { Office of Population } \\
\text { Censuses and } \\
\text { Surveys, } 1986 \text { (11) }\end{array}$ & Great Britain & $\begin{array}{l}1979-1980 \& \\
1982-1983\end{array}$ & rs & $\begin{array}{l}20-64 \\
20-64\end{array}$ & $\begin{array}{l}\text { Male } \\
\text { Male }\end{array}$ & $\begin{array}{r}9 \\
11\end{array}$ & $\begin{array}{l}\text { SMR } \\
\text { SMR }\end{array}$ & $\begin{array}{l}0.89 \\
2.92\end{array}$ & $\begin{array}{l}041-1.69^{\circ} \\
1.46-5.22^{\mathrm{b}}\end{array}$ \\
\hline $\begin{array}{l}\text { Coggon et al, } \\
1995 \text { (1) }\end{array}$ & England and Wales & $\begin{array}{l}1979-19 \\
1982-19\end{array}$ & $\begin{array}{l}\text { Nonuniversity teachers } \\
\text { Nonuniversity teachers } \\
\text { Teachers in higher education } \\
\text { Teachers in higher education }\end{array}$ & $\begin{array}{l}20-74 \\
20-74 \\
20-74 \\
20-74\end{array}$ & $\begin{array}{l}\text { Male } \\
\text { Female } \\
\text { Male } \\
\text { Female }\end{array}$ & $\begin{array}{r}52 \\
38 \\
22 \\
3\end{array}$ & $\begin{array}{l}\text { PMR } \\
\text { PMR } \\
\text { PMR } \\
\text { PMR }\end{array}$ & $\begin{array}{l}1.54^{b} \\
1.41^{b} \\
2.35^{b} \\
4.05^{b}\end{array}$ & $\begin{array}{r}1.15-2.02^{\mathrm{b}} \\
1.00-1.94^{\mathrm{b}} \\
1.47-3.56^{\mathrm{b}} \\
0.84-11.80^{\mathrm{b}}\end{array}$ \\
\hline Milham, 1997 (14) & Washington State & $\begin{array}{l}1950-1989 \\
1974-1989\end{array}$ & $\begin{array}{l}\text { School teachers } \\
\text { Professors and instructors } \\
\text { School teachers }\end{array}$ & $\begin{array}{l}20-64 \\
20-64 \\
20-64\end{array}$ & $\begin{array}{l}\text { Male } \\
\text { Male } \\
\text { Female }\end{array}$ & $\begin{array}{l}7 \\
1 \\
1\end{array}$ & $\begin{array}{l}\text { PMR } \\
\text { PMR } \\
\text { PMR }\end{array}$ & $\begin{array}{r}2.38 \\
-\end{array}$ & $\begin{array}{c}0.96-4.90^{\circ} \\
\cdots \\
\cdots\end{array}$ \\
\hline $\begin{array}{l}\text { Petersen \& Milham, } \\
1980 \text { (16) }\end{array}$ & California State & $1959-1961$ & $\begin{array}{l}\text { Teachers } \\
\text { Professors and instructors }\end{array}$ & $\begin{array}{l}\geq 20 \\
\geq 20\end{array}$ & $\begin{array}{l}\text { Male } \\
\text { Male }\end{array}$ & $\begin{array}{l}1 \\
2\end{array}$ & $\begin{array}{l}\text { PMR } \\
\text { PMR }\end{array}$ & $\begin{array}{l}0.70 \\
1.88\end{array}$ & $\begin{array}{l}0.02-3.90^{\circ} \\
0.23-6.82^{\circ}\end{array}$ \\
\hline $\begin{array}{l}\text { Morton \& } \\
\text { Marjanovic, } \\
1984(19)\end{array}$ & Portland-Va & $1963-1977$ & $\begin{array}{l}\text { School teachers } \\
\text { School teachers } \\
\text { College professors } \\
\text { College professors }\end{array}$ & $\begin{array}{l}16-74 \\
16-74 \\
16-74 \\
16-74\end{array}$ & $\begin{array}{l}\text { Male } \\
\text { Female } \\
\text { Male } \\
\text { Female }\end{array}$ & $\begin{array}{l}6 \\
8 \\
- \\
-\end{array}$ & $\begin{array}{l}\mathrm{RR} \\
\mathrm{RR} \\
\mathrm{RR} \\
\mathrm{RR}\end{array}$ & $\begin{array}{c}2.3^{b} \\
2.9^{b} \\
0 \\
0\end{array}$ & $\begin{array}{l}. . \\
. . \\
. . \\
. .\end{array}$ \\
\hline $\begin{array}{l}\text { Burnett et al, } \\
1997(20)\end{array}$ & $\begin{array}{l}\text { United States } \\
\text { (24 states) }\end{array}$ & $1984-1988$ & Teachers except postsecondaryc & $\geq 20$ & Female & 114 & PMR & 1.30 & $1.07-1.56$ \\
\hline Dewar, $1986(24)$ & Pennsylvania & $1983-1984$ & $\begin{array}{l}\text { Primary and secondary teachers } \\
\text { Primary and secondary teachers } \\
\text { Primary and secondary teachers }\end{array}$ & $\begin{array}{l}\text { All } \\
\text { All } \\
\text { All }\end{array}$ & $\begin{array}{l}\text { Male } \\
\text { Female } \\
\text { Female }\end{array}$ & $\begin{array}{l}4 \\
7 \\
1\end{array}$ & $\begin{array}{l}\text { PMR } \\
\text { PMR } \\
\text { PMR }\end{array}$ & $\begin{array}{l}1.84 \\
0.94 \\
9.09\end{array}$ & $\begin{array}{r}0.50-4.71^{\mathrm{b}} \\
0.38-1.94^{\mathrm{b}} \\
0.23-50.60^{\mathrm{b}}\end{array}$ \\
\hline
\end{tabular}

${ }^{3}$ Approximate summary estimates of relative risk: studies based on incidence or mortality rates: number of cases $34, \mathrm{RR} 1.77,95 \% \mathrm{Cl} 1.22-2.47$; studies based on proportional mortality, mortality odds ratios or proportional cancer incidence: number of cases $251, \mathrm{RR} 1.45,95 \% \mathrm{Cl} 1.27-1.64$. ${ }^{b}$ Calculated by us.

cWhites only.

a Blacks only.

Table 3. Summary of findings for nonlymphatic leukemia. ${ }^{a}(\mathrm{RR}=$ relative risk, $95 \% \mathrm{Cl}=95 \%$ confidence interval, $\mathrm{SMR}=$ standardized mortality ratio, PMR = proportional mortality ratio)

\begin{tabular}{|c|c|c|c|c|c|c|c|c|c|}
\hline Reference & Place & Period & Occupation & $\begin{array}{c}\text { Age } \\
\text { (years) }\end{array}$ & Gender & $\begin{array}{l}\text { Number } \\
\text { of cases }\end{array}$ & $\begin{array}{c}\text { Measure } \\
\text { of risk }\end{array}$ & $R R$ & $95 \% \mathrm{Cl}$ \\
\hline $\begin{array}{l}\text { Office of Population } \\
\text { Censuses and } \\
\text { Surveys, } 1986 \text { (11) }\end{array}$ & Great Britain & $\begin{array}{l}1979-1980 \& \\
1982-1983\end{array}$ & $\begin{array}{l}\text { Nonuniversity teachers } \\
\text { Teachers in higher education }\end{array}$ & $\begin{array}{l}20-64 \\
20-64\end{array}$ & $\begin{array}{l}\text { Male } \\
\text { Male }\end{array}$ & $\begin{array}{r}35 \\
5\end{array}$ & $\begin{array}{l}\text { SMR } \\
\text { SMR }\end{array}$ & $\begin{array}{l}1.33^{d} \\
0.50^{d}\end{array}$ & $\begin{array}{l}0.93-1.85^{\mathrm{b}} \\
0.16-1.17^{\mathrm{b}}\end{array}$ \\
\hline $\begin{array}{l}\text { Coggon et al } \\
1995(1)\end{array}$ & England and Wales & $\begin{array}{l}1979-1980 \& \\
1982-1990\end{array}$ & $\begin{array}{l}\text { Nonuniversity teachers } \\
\text { Nonuniversity teachers } \\
\text { Teachers in higher education } \\
\text { Teachers in higher education }\end{array}$ & $\begin{array}{l}20-74 \\
20-74 \\
20-74 \\
20-74\end{array}$ & $\begin{array}{l}\text { Male } \\
\text { Female } \\
\text { Male } \\
\text { Female }\end{array}$ & $\begin{array}{r}132 \\
148 \\
44 \\
17\end{array}$ & $\begin{array}{l}\text { PMR } \\
\text { PMR } \\
\text { PMR } \\
\text { PMR }\end{array}$ & $\begin{array}{l}1.58^{\mathrm{b}} \\
1.34^{\mathrm{b}} \\
1.90^{\mathrm{b}} \\
1.99^{\mathrm{b}}\end{array}$ & $\begin{array}{l}1.32-1.87^{b} \\
1.13-1.57^{b} \\
1.38-2.55^{b} \\
1.16-3.19^{b}\end{array}$ \\
\hline Milham, 1997 (14) & Washington State & $\begin{array}{l}1950-1989 \\
1974-1989\end{array}$ & $\begin{array}{l}\text { School teachers } \\
\text { Professors and instructors } \\
\text { School teachers }\end{array}$ & $\begin{array}{l}20-64 \\
20-64 \\
20-64\end{array}$ & $\begin{array}{l}\text { Male } \\
\text { Male } \\
\text { Female }\end{array}$ & $\begin{array}{l}7 \\
2 \\
7\end{array}$ & $\begin{array}{l}\text { PMR } \\
\text { PMR } \\
\text { PMR }\end{array}$ & $\begin{array}{l}1.83^{d} \\
1.99^{d} \\
2.54^{d}\end{array}$ & $\begin{array}{l}074-3.77^{b} \\
0.24-7.19^{b} \\
1.02-5.23^{b}\end{array}$ \\
\hline $\begin{array}{l}\text { Petersen \& Milham, } \\
1980(16)\end{array}$ & California State & $1959-1961$ & $\begin{array}{l}\text { Teachers } \\
\text { Protessors and instructors }\end{array}$ & $\begin{array}{l}\geq 20 \\
\geq 20\end{array}$ & $\begin{array}{l}\text { Male } \\
\text { Male }\end{array}$ & - & $\begin{array}{l}\text { PMR } \\
\text { PMR }\end{array}$ & $\begin{array}{l}0^{\mathrm{d}} \\
0^{\mathrm{d}}\end{array}$ & $\begin{array}{l}. . \\
. .\end{array}$ \\
\hline $\begin{array}{l}\text { Morton \& } \\
\text { Marjanovic, } \\
1984(19)\end{array}$ & Portland-Vancouver & $1963-1977$ & $\begin{array}{l}\text { School teachers } \\
\text { School teachers } \\
\text { College professors } \\
\text { College professors }\end{array}$ & $\begin{array}{l}16-74 \\
16-74 \\
16-74 \\
16-74\end{array}$ & $\begin{array}{l}\text { Male } \\
\text { Female } \\
\text { Male } \\
\text { Female }\end{array}$ & $\begin{array}{l}4 \\
5 \\
- \\
2\end{array}$ & $\begin{array}{l}\text { RR } \\
R R \\
R R \\
R R\end{array}$ & $\begin{array}{l}1.9^{b} \\
0.9^{b} \\
0 \\
4.8^{b}\end{array}$ & $\begin{array}{l}. . \\
. . \\
. . \\
. .\end{array}$ \\
\hline $\begin{array}{l}\text { Burnett et al, } \\
1997(20)\end{array}$ & $\begin{array}{l}\text { United States } \\
\text { (24 states) }\end{array}$ & $1984-1988$ & Teachers except postsecondaryc & $\geq 20$ & Female & 177 & PMR & $1.31 d$ & $1.13-1.52$ \\
\hline Dewar, $1986(24)$ & Pennsylvania & $1983-1984$ & Primary and secondary teachers ${ }^{c}$ & All & Female & 13 & PMR & $1.11^{\circ}$ & $0.59-1.90^{b}$ \\
\hline
\end{tabular}

a Approximate summary estimates of relative risk: studies based on incidence or mortality rates: number of cases $51, \mathrm{RR} 1.15,95 \% \mathrm{Cl0.86-1.51 \text {; }}$ studies based on proportional mortality, mortality odds ratios or proportional cancer incidence: number of cases $547, \mathrm{RR} 1.44,95 \% \mathrm{Cl} 1.32-1.56$. b Calculated by us

c Whites only.

"Myeloid leukemia only.

Thus, if teachers have low mortality from all causes combined [the all-cause SMR for male teachers aged 20-64 years in Great Britain during 1979-1980 and
1982 - 1983 was only 0.61 (11)], PMR values and mortality odds ratios will tend to be elevated for leukemia even when the death rate from the disease is not 
Table 4. Summary of findings for Hodgkin's disease. ${ }^{a}(R R=$ relative risk, $95 \% \mathrm{Cl}=95 \%$ confidence interval, $S M R=$ standardized mortality ratio, $\mathrm{PMR}=$ proportional mortality ratio, $\mathrm{SIR}=$ standardized incidence ratio, $\mathrm{SPIR}=$ standardized proportional incidence ratio)

\begin{tabular}{|c|c|c|c|c|c|c|c|c|c|}
\hline Reference & Place & Period & Occupation & $\begin{array}{l}\text { Age } \\
\text { (years) }\end{array}$ & Gender & $\begin{array}{l}\text { Number } \\
\text { of cases }\end{array}$ & $\begin{array}{l}\text { Measure } \\
\text { of risk }\end{array}$ & $R R$ & $95 \% \mathrm{Cl}$ \\
\hline $\begin{array}{l}\text { Office of Population } \\
\text { Censuses and } \\
\text { Surveys, } 1978(10)\end{array}$ & England and Wales & $1970-1972$ & $\begin{array}{l}\text { Primary and secor } \\
\text { Primary and secor }\end{array}$ & $\begin{array}{l}15-64 \\
65-74\end{array}$ & $\begin{array}{l}\text { Male } \\
\text { Male }\end{array}$ & $\begin{array}{r}18 \\
2\end{array}$ & $\begin{array}{l}\text { SMR } \\
\text { PMR }\end{array}$ & $\begin{array}{l}1.43 \\
1.49\end{array}$ & $\begin{array}{l}0.85-2.26^{\circ} \\
0.18-5.38^{\circ}\end{array}$ \\
\hline $\begin{array}{l}\text { Office of Population } \\
\text { Censuses and } \\
\text { Surveys } 1986(11)\end{array}$ & Great Britain & $\begin{array}{l}1979-1980 \& \& \\
1982-1983\end{array}$ & Iucation & $\begin{array}{l}20-64 \\
20-64\end{array}$ & $\begin{array}{l}\text { Male } \\
\text { Male }\end{array}$ & $\begin{array}{r}14 \\
4\end{array}$ & $\begin{array}{l}\text { MR } \\
\text { MR }\end{array}$ & $\begin{array}{l}0.87 \\
0.70\end{array}$ & $\begin{array}{l}0.48-1.46^{b} \\
0.19-1.79^{b}\end{array}$ \\
\hline $\begin{array}{l}\text { Coggon et al, } \\
1995(1)\end{array}$ & England and Wales & $\begin{array}{l}1979-1 \\
1982-1\end{array}$ & $\begin{array}{l}\text { Nonuniversity teachers } \\
\text { Nonuniversity teachers } \\
\text { Teachers in higher education } \\
\text { Teachers in higher education }\end{array}$ & $\begin{array}{l}20-74 \\
20-74 \\
20-74 \\
20-74\end{array}$ & $\begin{array}{l}\text { Male } \\
\text { Female } \\
\text { Male } \\
\text { Female }\end{array}$ & $\begin{array}{r}44 \\
45 \\
10 \\
1\end{array}$ & $\begin{array}{l}\text { PMR } \\
\text { PMR } \\
\text { PMR } \\
\text { PMR }\end{array}$ & $\begin{array}{l}1.57 \\
1.85 \\
1.31 \\
0.63\end{array}$ & $\begin{array}{l}1.14-2.12 \\
1.35-2.48 \\
0.63-2.42 \\
0.02-3.51\end{array}$ \\
\hline Mitham, 1997 (14) & Washington State & $\begin{array}{l}1950-1989 \\
1974-1989\end{array}$ & $\begin{array}{l}\text { School teachers } \\
\text { Professors and instructors } \\
\text { School teachers }^{c}\end{array}$ & $\begin{array}{l}20-64 \\
20-64 \\
20-64\end{array}$ & $\begin{array}{l}\text { Male } \\
\text { Male } \\
\text { Female }\end{array}$ & $\begin{array}{r}13 \\
3\end{array}$ & $\begin{array}{l}\text { PMR } \\
\text { PMR } \\
\text { PMR }\end{array}$ & $\begin{array}{r}1.90 \\
0 \\
1.07\end{array}$ & $\begin{array}{l}1.01-3.25^{\mathrm{b}} \\
0.22-3.13^{\mathrm{b}}\end{array}$ \\
\hline $\begin{array}{l}\text { Petersen \& Milham, } \\
1980(16)\end{array}$ & Galifor & $1959-1961$ & $\begin{array}{l}\text { Teachers } \\
\text { Professors and instructors }\end{array}$ & $\begin{array}{l}\geq 20 \\
\geq 20\end{array}$ & $\begin{array}{l}\text { Male } \\
\text { Male }\end{array}$ & $\begin{array}{l}4 \\
2\end{array}$ & $\begin{array}{l}\text { PMR } \\
\text { PMR }\end{array}$ & $\begin{array}{l}1.65 \\
1.44\end{array}$ & $\begin{array}{l}0.45-4.23^{\mathrm{b}} \\
0.17-5.20^{\mathrm{b}}\end{array}$ \\
\hline $\begin{array}{l}\text { Hrubec et al, } \\
1992(17)\end{array}$ & USA ( & $1954-1980$ & $\begin{array}{l}\text { Teachers (nonsmokers) } \\
\text { Teachers (smokers) }\end{array}$ & $\begin{array}{l}\text { All } \\
\text { All }\end{array}$ & $\begin{array}{l}\text { Male } \\
\text { Male }\end{array}$ & $\begin{array}{l}2 \\
1\end{array}$ & $\begin{array}{l}\mathrm{RR} \\
\mathrm{RR}\end{array}$ & $\begin{array}{l}0.9 \\
0.5\end{array}$ & $\begin{array}{l}. . \\
. .\end{array}$ \\
\hline $\begin{array}{l}\text { Rosenman, } \\
1994 \text { (23) }\end{array}$ & New & $1980-1984$ & $\begin{array}{l}\text { Primary and secondary teachers } \\
\text { Primary and secondary teachers } \\
\text { Primary and secondary teachers } \\
\text { Primary and secondary teachers }\end{array}$ & $\begin{array}{l}\text { All } \\
\text { All } \\
\text { All } \\
\text { All }\end{array}$ & $\begin{array}{l}\text { Male } \\
\text { Male } \\
\text { Female } \\
\text { Female }\end{array}$ & $\begin{array}{l}- \\
4 \\
-\end{array}$ & $\begin{array}{l}\text { PMR } \\
\text { PMR } \\
\text { PMRe } \\
\text { PMR }\end{array}$ & $\begin{array}{r}0 \\
0 \\
5.25 \\
0\end{array}$ & $\begin{array}{c}. . \\
2.19-12.59 \\
. .\end{array}$ \\
\hline Dewar, 1986 (24) & Pennsylvania & $1983-1984$ & $\begin{array}{l}\text { Primary and secondary teachers } \\
\text { Primary and secondary teachers } \\
\text { Primary and secondary teachers }\end{array}$ & $\begin{array}{l}\text { All } \\
\text { All } \\
\text { All }\end{array}$ & $\begin{array}{l}\text { Male } \\
\text { Female } \\
\text { Female }\end{array}$ & $\begin{array}{l}1 \\
2 \\
1\end{array}$ & $\begin{array}{l}\text { PMR } \\
\text { PMR } \\
\text { PMR }\end{array}$ & $\begin{array}{l}0.89 \\
0.80 \\
6.67\end{array}$ & $\begin{array}{r}0.02-4.96^{\mathrm{b}} \\
0.10-2.89^{\mathrm{b}} \\
0.17-37.20^{\mathrm{b}}\end{array}$ \\
\hline $\begin{array}{l}\text { Grufferman et al, } \\
1976(25)\end{array}$ & Boston & $1959-1973$ & Teachers & $20-64$ & Both & 30 & SIR & 1.1 & $0.7-1.6$ \\
\hline $\begin{array}{l}\text { Olsen \& Jensen, } \\
1987(26)\end{array}$ & Denmark & $1970-1979$ & $\begin{array}{l}\text { Educational services } \\
\text { Educational services }\end{array}$ & $\begin{array}{l}18-66 \\
18-66\end{array}$ & $\begin{array}{l}\text { Male } \\
\text { Female }\end{array}$ & $\begin{array}{l}4 \\
3\end{array}$ & $\begin{array}{l}\text { SPIR } \\
\text { SPIR }\end{array}$ & $\begin{array}{l}0.93 \\
1.10\end{array}$ & $\begin{array}{l}0.35-2.48 \\
0.36-3.43\end{array}$ \\
\hline Roseo, 1995 (27) & Turin & $1981-1989$ & $\begin{array}{l}\text { Teachers and professors } \\
\text { Teachers and professors }\end{array}$ & $\begin{array}{l}\text { All } \\
\text { All }\end{array}$ & $\begin{array}{l}\text { Male } \\
\text { Female }\end{array}$ & $\overline{1}$ & $\begin{array}{l}\text { SMR } \\
\text { SMR }\end{array}$ & $\begin{array}{r}0 \\
1.23\end{array}$ & $0.03^{-.} 6.85^{\mathrm{b}}$ \\
\hline Roseo, 1995 (27) & Italy & $1981-1982$ & $\begin{array}{l}\text { Teachers and professors } \\
\text { Teachers and professors }\end{array}$ & $\begin{array}{l}18-64 \\
18-64\end{array}$ & $\begin{array}{l}\text { Male } \\
\text { Female }\end{array}$ & $\overline{4}$ & $\begin{array}{l}\text { MOR } \\
\text { MOR }\end{array}$ & $\begin{array}{r}0 \\
7.32\end{array}$ & $\begin{array}{l}. . \\
. .\end{array}$ \\
\hline King et al, 1994 (31) & British Columbia & $1950-1984$ & $\begin{array}{l}\text { School teachers } \\
\text { School teachers }\end{array}$ & $\begin{array}{l}\geq 20 \\
\geq 20\end{array}$ & $\begin{array}{l}\text { Male } \\
\text { Female }\end{array}$ & $\begin{array}{l}8 \\
2\end{array}$ & $\begin{array}{l}\text { PMR } \\
\text { PMR }\end{array}$ & $\begin{array}{l}1.87 \\
0.49\end{array}$ & $\begin{array}{l}0.80-3.69 \\
0.05-1.78\end{array}$ \\
\hline
\end{tabular}

a Approximate summary estimates of relative risk: studies based on incidence or mortality rates: number of cases $70, \mathrm{RR} 1.05,95 \% \mathrm{Cl} 0.82-1.33$; studies based on proportional mortality, mortality odds ratios or proportional cancer incidence: number of cases $153, \mathrm{RR} 1.58,95 \% \mathrm{Cl} 1.34-1.85$ - Calculated by us.

c Whites.

Blacks.

PMR based on United States proportions as standard.

increased. Spurious inflation of risk estimates in this way would not normally be specific to lymphatic and hematopoietic cancer, and, in this respect, it is notable that most of the proportional mortality analyses reviewed also showed elevated PMR values for melanoma and cancers of the colon, prostate, and brain among teachers. The same sort of effect could occur with proportional cancer incidence if the overall incidence of cancer among teachers were low, although this is perhaps less likely to be a major problem.

\section{Healthy worker effect}

Mortality in occupational populations is often lower than that in the general population because people with chronic disabling disease are excluded from or selected out of work, and this selection may sometimes obscure the effects of occupational hazards. For an occupation such as teaching, such bias should not affect studies based on the last full-time or main lifetime job (eg, the Registrar General's analyses of occupational mortality). It could be relevant in cohort studies based on current occupation at the time of entry to follow-up, but the effect tends to be less for cancer than for other common causes of death, such as cardiovascular or respiratory disease, and even in these types of investigations major bias seems unlikely.

\section{Confounding effects}

Several large cohort studies have suggested an association between leukemia and smoking (33-36), but the finding has not been universal (37), and, if leukemia incidence is increased for smokers, then it is unlikely to be by more than $50 \%$. Thus any confounding effect from smoking is likely to be weak. In the United Kingdom (UK), teachers smoke less than people in most other occupations (38), and this difference would, if anything, 
Table 5. Summary of findings for non-Hodgkin's lymphoma. ${ }^{a}(R R=$ relative risk, $95 \% \mathrm{Cl}=95 \%$ confidence interval, $S M R=$ standardized mortality ratio, $\mathrm{PMR}=$ proportional mortality ratio, $\mathrm{MOR}=$ mortality odds ratio, SIR $=$ standardized incidence ratio, $\mathrm{SPIR}=$ standardized proportional incidence ratio)

\begin{tabular}{|c|c|c|c|c|c|c|c|c|c|}
\hline Reference & Place & Period & Occupation & $\begin{array}{c}\text { Age } \\
\text { (years) }\end{array}$ & Gender & $\begin{array}{l}\text { Number } \\
\text { of cases }\end{array}$ & $\begin{array}{l}\text { Measure } \\
\text { of risk }\end{array}$ & $R R$ & $95 \% \mathrm{Cl}$ \\
\hline $\begin{array}{l}\text { Office of Population } \\
\text { Censuses and } \\
\text { Surveys, } 1978(10)\end{array}$ & England and Wales & $1970-1972$ & $\begin{array}{l}\text { Primary and secon } \\
\text { Primary and secon }\end{array}$ & $\begin{array}{l}15-64 \\
65-74\end{array}$ & $\begin{array}{l}\text { Male } \\
\text { Male }\end{array}$ & $\begin{array}{r}19 \\
6\end{array}$ & $\begin{array}{l}\text { SMR } \\
\text { PMR }\end{array}$ & $\begin{array}{l}1.55^{b} \\
1.98^{b}\end{array}$ & $\begin{array}{l}0.93-2.42^{\circ} \\
0.73-4.31^{\circ}\end{array}$ \\
\hline $\begin{array}{l}\text { Coggon et al, } \\
1995 \text { (1) }\end{array}$ & England and Wales & $\begin{array}{l}1979-1980 \& \& \\
1982-1990\end{array}$ & $\begin{array}{l}\text { Nonuniversity teachers } \\
\text { Nonuniversity teachers } \\
\text { Teachers in higher education } \\
\text { Teachers in higher education }\end{array}$ & $\begin{array}{l}20-74 \\
20-74 \\
20-74 \\
20-74\end{array}$ & $\begin{array}{l}\text { Male } \\
\text { Female } \\
\text { Male } \\
\text { Female }\end{array}$ & $\begin{array}{r}201 \\
180 \\
69 \\
9\end{array}$ & $\begin{array}{l}\text { PMR } \\
\text { PMR } \\
\text { PMR } \\
\text { PMR }\end{array}$ & $\begin{array}{l}1.72 \\
1.38 \\
1.98 \\
1.11\end{array}$ & $\begin{array}{l}1.49-1.97 \\
1.18-1.60 \\
1.54-2.50 \\
0.51-2.11\end{array}$ \\
\hline Milham, 1997 (14) & Washington State & $\begin{array}{l}1950-1989 \\
1974-1989\end{array}$ & $\begin{array}{l}\text { School teachers } \\
\text { Professors and instructors } \\
\text { School teachers }\end{array}$ & $\begin{array}{l}20-64 \\
20-64 \\
20-64\end{array}$ & $\begin{array}{l}\text { Male } \\
\text { Male } \\
\text { Female }\end{array}$ & $\begin{array}{r}18 \\
5 \\
14\end{array}$ & $\begin{array}{l}\text { PMR } \\
\text { PMR } \\
\text { PMR }\end{array}$ & $\begin{array}{l}2.39 \\
2.48 \\
1.76\end{array}$ & $\begin{array}{l}1.42-3.78 \\
0.81-5.79 \\
0.96-2.95\end{array}$ \\
\hline $\begin{array}{l}\text { Petersen \& Milham, } \\
1980(16)\end{array}$ & California State & $1959-1961$ & Teachers $^{\mathrm{d}}$ & $\geq 20$ & Male & 7 & PMR & $1.4^{\circ}$ & $0.56-2.88^{c}$ \\
\hline $\begin{array}{l}\text { Hrubec et al, } \\
1992(17)\end{array}$ & $\begin{array}{l}\text { United States } \\
\text { (veterans) }\end{array}$ & $1954-1980$ & $\begin{array}{l}\text { Teachers (non-smokers) } \\
\text { Teachers (smokers) }\end{array}$ & $\begin{array}{l}\text { All } \\
\text { All }\end{array}$ & $\begin{array}{l}\text { Male } \\
\text { Male }\end{array}$ & $\begin{array}{r}13 \\
8\end{array}$ & $\begin{array}{l}\mathrm{RR} \\
\mathrm{RR}\end{array}$ & $\begin{array}{l}1.1 \\
1.1\end{array}$ & $\begin{array}{l}0.6-1.9^{c} \\
0.5-2.2^{c}\end{array}$ \\
\hline $\begin{array}{l}\text { Burnett et al, } \\
1997(20)\end{array}$ & $\begin{array}{l}\text { United States } \\
\text { (24 states) }\end{array}$ & $1984-1988$ & $\begin{array}{l}\text { Teachers post secondaryd } \\
\text { Teachers except post secondary }\end{array}$ & $\begin{array}{l}\geq 20 \\
\geq 20\end{array}$ & $\begin{array}{l}\text { Male } \\
\text { Male }\end{array}$ & $\begin{array}{r}34 \\
121\end{array}$ & $\begin{array}{l}\text { PMR } \\
\text { PMR }\end{array}$ & $\begin{array}{l}1.57 \\
1.68\end{array}$ & $\begin{array}{l}1.09-2.19 \\
1.40-2.01\end{array}$ \\
\hline $\begin{array}{l}\text { Figgs et al, } \\
1995(21)\end{array}$ & $\begin{array}{l}\text { United States } \\
\text { (24 states) }\end{array}$ & $1984-1989$ & $\begin{array}{l}\text { Art, drama and music teachers } \\
\text { Elementary teachers } \\
\text { Elementary teachers }^{d} \\
\text { Elementary teachers } \\
\text { Secondary teachers } \\
\text { Secondary teachers }^{d} \\
\text { Post secondary teachers } \\
\text { Other teachers }\end{array}$ & $\begin{array}{l}\text { All } \\
\text { All } \\
\text { All } \\
\text { All } \\
\text { All } \\
\text { All } \\
\text { All } \\
\text { All }\end{array}$ & $\begin{array}{l}\text { Male } \\
\text { Male } \\
\text { Female } \\
\text { Female } \\
\text { Male } \\
\text { Female } \\
\text { Male } \\
\text { Female }\end{array}$ & $\begin{array}{r}5 \\
105 \\
451 \\
23 \\
33 \\
62 \\
30 \\
31\end{array}$ & $\begin{array}{l}\text { MOR } \\
\text { MOR } \\
\text { MOR } \\
\text { MOR } \\
\text { MOR } \\
\text { MOR } \\
\text { MOR } \\
\text { MOR }\end{array}$ & $\begin{array}{l}3.6 \\
1.6 \\
1.4 \\
1.8 \\
1.6 \\
1.7 \\
1.7 \\
1.6\end{array}$ & $\begin{array}{l}1.2-11.5 \\
1.3-2.0 \\
1.2-1.5 \\
1.1-2.9 \\
1.1-2.3 \\
1.3-2.3 \\
1.1-2.6 \\
1.1-2.4\end{array}$ \\
\hline Dewar, 1986 (24) & Pennsylvanía & $1983-1984$ & $\begin{array}{l}\text { Primary and secondary teachers } \\
\text { Primary and secondary teachers }\end{array}$ & $\begin{array}{l}\text { All } \\
\text { All }\end{array}$ & $\begin{array}{l}\text { Male } \\
\text { Female }\end{array}$ & $\begin{array}{l}13 \\
21\end{array}$ & $\begin{array}{l}\text { PMR } \\
\text { PMR }\end{array}$ & $\begin{array}{l}1.85^{c} \\
0.85^{c}\end{array}$ & $\begin{array}{l}0.99-3.16^{c} \\
0.53-1.30^{c}\end{array}$ \\
\hline $\begin{array}{l}\text { OIsen \& Jensen, } \\
1987(26)\end{array}$ & Denmark & $1970-1979$ & $\begin{array}{l}\text { Educational services } \\
\text { Educational services }\end{array}$ & $\begin{array}{l}18-66 \\
18-66\end{array}$ & $\begin{array}{l}\text { Male } \\
\text { Female }\end{array}$ & $\begin{array}{l}7 \\
2\end{array}$ & $\begin{array}{l}\text { SPIR } \\
\text { SPIR }\end{array}$ & $\begin{array}{l}0.89 \\
0.31\end{array}$ & $\begin{array}{l}0.43-1.88 \\
0.08-1.23\end{array}$ \\
\hline Roseo, 1995 (27) & Turin & $1981-1989$ & $\begin{array}{l}\text { Teachers and professors } \\
\text { Teachers and professors }\end{array}$ & $\begin{array}{l}\text { All } \\
\text { All }\end{array}$ & $\begin{array}{l}\text { Male } \\
\text { Female }\end{array}$ & $\begin{array}{l}2 \\
1\end{array}$ & $\begin{array}{l}\text { SMR } \\
\text { SMR }\end{array}$ & $\begin{array}{l}1.37 \\
0.56\end{array}$ & $\begin{array}{l}0.17-4.95^{c} \\
0.01-3.12^{c}\end{array}$ \\
\hline Roseo, 1995 (27) & Italy & $1981-1982$ & $\begin{array}{l}\text { Teachers and professors } \\
\text { Teachers and professors }\end{array}$ & $\begin{array}{l}18-64 \\
18-64\end{array}$ & $\begin{array}{c}\text { Male } \\
\text { Female }\end{array}$ & $\begin{array}{l}3 \\
5\end{array}$ & $\begin{array}{l}\text { MOR } \\
\text { MOR }\end{array}$ & $\begin{array}{l}2.33 \\
3.19\end{array}$ & $\begin{array}{l}. . \\
. .\end{array}$ \\
\hline Pukkala, 1995 (28) & Finland & $1971-1985$ & $\begin{array}{l}\text { All teachers } \\
\text { All teachers }\end{array}$ & $\begin{array}{l}35-64 \\
35-64\end{array}$ & $\begin{array}{l}\text { Male } \\
\text { Female }\end{array}$ & $\begin{array}{l}25 \\
15\end{array}$ & $\begin{array}{l}\text { SIR } \\
\text { SIR }\end{array}$ & $\begin{array}{l}1.36 \\
1.04\end{array}$ & $\begin{array}{l}0.88-2.01 \\
0.58-1.71\end{array}$ \\
\hline Linet et al, $1993(30)$ & Sweden & $1961-1979$ & $\begin{array}{l}\text { School teachers } \\
\text { Special teachers }\end{array}$ & $\begin{array}{l}\text { All } \\
\text { All }\end{array}$ & $\begin{array}{l}\text { Male } \\
\text { Male }\end{array}$ & $\begin{array}{l}14 \\
24\end{array}$ & $\begin{array}{l}\text { SIR } \\
\text { SIR }\end{array}$ & $\begin{array}{l}2.1 \\
1.6\end{array}$ & $\begin{array}{l}1.2-3.5^{c} \\
1.0-2.4^{\circ}\end{array}$ \\
\hline King et al, 1994 (31) & British Columbia & $1950-1984$ & $\begin{array}{l}\text { School teachers } \\
\text { School teachers }\end{array}$ & $\begin{array}{l}\geq 20 \\
\geq 20\end{array}$ & $\begin{array}{c}\text { Male } \\
\text { Female }\end{array}$ & $\begin{array}{l}16 \\
15\end{array}$ & $\begin{array}{l}\text { PMR } \\
\text { PMR }\end{array}$ & $\begin{array}{l}1.43^{c} \\
0.97^{c}\end{array}$ & $\begin{array}{l}0.82-2.32^{c} \\
0.54-1.60^{\circ}\end{array}$ \\
\hline
\end{tabular}

a Approximate summary estimates of relative risk: studies based on incidence or mortality rates: number of cases $121, \mathrm{RR} 1.36,95 \% \mathrm{Cl} 1.13-1.62$;

studies based on proportional mortality, mortality odds ratios or proportional cancer incidencet: number of cases $1331, \mathrm{RR} 1.50,95 \% \mathrm{CI} 1.42-1.58$.

b International Classification of Diseases, code 200 only.

c Calculated by us.

d White.

e Black.

${ }^{1}$ Excludes reference 20 because of overlap by reference 21 .

tend to obscure an occupational hazard. None of the wellestablished causes of leukemia or lymphoma (genetic disorders such as ataxia telangiectasia, ionizing radiation, benzene or immunosuppressive drugs) is likely to be strongly associated with work as a teacher.

\section{Statistical power}

The weight that can be given to individual studies depends not only on the potential influences of bias and confounding, but also on their statistical power. We have calculated approximate summary estimates of risk for the 2 main categories of study, which take into account their relative size. However, these estimates must be interpreted with caution. They are crude in so far as they ignore differences between studies in the precision of expected numbers and treat different measures of risk (eg, SMR values and odds ratios) as directly comparable. Furthermore, they not only exclude unpublished findings, but also those for which the information reported was insufficient for analysis (eg, where there were no cases of disease among teachers but the expected number was not given). In addition, there may have been some "double counting" because of overlap between studies (eg, those of cancer registrations and occupational mortality in the United Kingdom). 
Table 6. Summary of findings for multiple myeloma. ${ }^{a}(R R=$ relative risk, $95 \% \mathrm{Cl}=95 \%$ confidence interval, SMR $=$ standardized mortality ratio, $P M R=$ proportional mortality ratio, $M O R=$ mortality odds ratio, $S I R=$ standardized incidence ratio)

\begin{tabular}{|c|c|c|c|c|c|c|c|c|c|}
\hline Reference & Place & Period & Occupation & $\begin{array}{c}\text { Age } \\
\text { (years) }\end{array}$ & Gender & $\begin{array}{l}\text { Number } \\
\text { of cases }\end{array}$ & $\begin{array}{c}\text { Measure } \\
\text { of risk }\end{array}$ & e RR & $95 \% \mathrm{Cl}$ \\
\hline $\begin{array}{l}\text { Coggon et al, } \\
1995(1)\end{array}$ & England and Wales & $\begin{array}{l}1979-1980 \& \\
1982-1990\end{array}$ & $\begin{array}{l}\text { Nonuniversity teachers } \\
\text { Nonuniversity teachers } \\
\text { Teachers in higher education } \\
\text { Teachers in higher education }\end{array}$ & $\begin{array}{l}20-74 \\
20-74 \\
20-74 \\
20-74\end{array}$ & $\begin{array}{l}\text { Male } \\
\text { Female } \\
\text { Male } \\
\text { Female }\end{array}$ & $\begin{array}{r}107 \\
95 \\
38 \\
7\end{array}$ & $\begin{array}{l}\text { PMR } \\
\text { PMR } \\
\text { PMR } \\
\text { PMR }\end{array}$ & $\begin{array}{l}1.69 \\
1.25 \\
2.05 \\
1.61\end{array}$ & $\begin{array}{l}1.39-2.05 \\
1.01-1.53 \\
1.45-2.81 \\
0.65-3.32\end{array}$ \\
\hline $\begin{array}{l}\text { Roman \& Carpenter, } \\
1995 \text { (12) }\end{array}$ & England & $1981-1987$ & Non-university teachers & $20-74$ & Male & 60 & PRR & 1.44 & $1.11-1.87^{b}$ \\
\hline Milham, $1997(14)$ & Washington State & $\begin{array}{l}1950-1989 \\
1974-1989\end{array}$ & $\begin{array}{l}\text { School teachers } \\
\text { Professors and instructors } \\
\text { School teachers }\end{array}$ & $\begin{array}{l}20-64 \\
20-64 \\
20-64\end{array}$ & $\begin{array}{l}\text { Male } \\
\text { Male } \\
\text { Female }\end{array}$ & $\begin{array}{l}9 \\
4 \\
8\end{array}$ & $\begin{array}{l}\text { PMR } \\
\text { PMR } \\
\text { PMR }\end{array}$ & $\begin{array}{l}1.61 \\
2.58 \\
1.69\end{array}$ & $\begin{array}{l}0.74-3.06^{\mathrm{b}} \\
0.70-6.61^{\mathrm{b}} \\
0.73-3.33^{\mathrm{b}}\end{array}$ \\
\hline $\begin{array}{l}\text { Petersen \& Milham, } \\
1980(16)\end{array}$ & California State & $1959-1961$ & $\begin{array}{l}\text { Teachers } \\
\text { Professors and Instructors }\end{array}$ & $\begin{array}{l}\geq 20 \\
\geq 20\end{array}$ & $\begin{array}{l}\text { Male } \\
\text { Male }\end{array}$ & $\begin{array}{l}3 \\
3\end{array}$ & $\begin{array}{l}\text { PMR } \\
\text { PMR }\end{array}$ & $\begin{array}{l}1.88 \\
2.55\end{array}$ & $\begin{array}{l}0.39-5.48^{b} \\
0.52-7.43^{b}\end{array}$ \\
\hline $\begin{array}{l}\text { Hrubec et al, } \\
1992(17)\end{array}$ & $\begin{array}{l}\text { United States } \\
\text { (veterans) }\end{array}$ & $1954-1980$ & $\begin{array}{l}\text { Teachers (nonsmokers) } \\
\text { Teachers (smokers) }\end{array}$ & $\begin{array}{l}\text { All } \\
\text { All }\end{array}$ & $\begin{array}{l}\text { Male } \\
\text { Male }\end{array}$ & $\begin{array}{l}7 \\
4\end{array}$ & $\begin{array}{l}\mathrm{RR} \\
\mathrm{RR}\end{array}$ & $\begin{array}{l}1.1 \\
1.2\end{array}$ & $\frac{0.5-2.4^{\circ}}{1.2}$ \\
\hline $\begin{array}{l}\text { Dubrow \& Wegman, } \\
1984(18)\end{array}$ & Massachusetts & $1971-1973$ & School professions ${ }^{c}$ & $\geq 20$ & Male & 5 & MOR & 2.97 & .. \\
\hline $\begin{array}{l}\text { Burnett et al, } \\
1997(20)\end{array}$ & $\begin{array}{l}\text { United States } \\
\text { (24 states) }\end{array}$ & $1984-1988$ & $\begin{array}{l}\text { Teachers postsecondaryc } \\
\text { Teachers except postsecondaryc } \\
\text { Teachers except postsecondaryc }\end{array}$ & $\begin{array}{l}\geq 20 \\
\geq 20 \\
\geq 20\end{array}$ & $\begin{array}{l}\text { Male } \\
\text { Male } \\
\text { Female }\end{array}$ & $\begin{array}{r}22 \\
61 \\
203\end{array}$ & $\begin{array}{l}\text { PMR } \\
\text { PMR } \\
\text { PMR }\end{array}$ & $\begin{array}{l}2.11 \\
1.80 \\
1.33\end{array}$ & $\begin{array}{l}1.32-3.19 \\
1.38-2.32 \\
1.16-1.53\end{array}$ \\
\hline $\begin{array}{l}\text { Figgs et al, } \\
1994(22)\end{array}$ & $\begin{array}{l}\text { United States } \\
\text { (24 states) }\end{array}$ & $1984-1989$ & $\begin{array}{l}\text { Elementary teachers }{ }^{c} \\
\text { Elementary teachers }^{c} \\
\text { Elementary teachers } \\
\text { Postsecondary teachers }\end{array}$ & $\begin{array}{l}\text { All } \\
\text { All } \\
\text { All } \\
\text { All }\end{array}$ & $\begin{array}{l}\text { Male } \\
\text { Female } \\
\text { Female } \\
\text { Female }\end{array}$ & $\begin{array}{r}64 \\
224 \\
38 \\
5\end{array}$ & $\begin{array}{l}\text { MOR } \\
\text { MOR } \\
\text { MOR } \\
\text { MOR }\end{array}$ & $\begin{array}{r}1.8 \\
1.5 \\
1.6 \\
26.8\end{array}$ & $\begin{array}{c}1.4-2.5 \\
1.3-1.8 \\
1.1-2.4 \\
3.1-233.3\end{array}$ \\
\hline Dewar, 1986 (24) & Pennsylvania & $1983-1984$ & $\begin{array}{l}\text { Primary and secondary teachers } \\
\text { Primary and secondary teachers } \\
\text { Primary and secondary teachers }\end{array}$ & $\begin{array}{l}\text { All } \\
\text { All } \\
\text { All }\end{array}$ & $\begin{array}{l}\text { Male } \\
\text { Female } \\
\text { Nale }\end{array}$ & $\begin{array}{r}5 \\
22 \\
1\end{array}$ & $\begin{array}{l}\text { PMR } \\
\text { PMR } \\
\text { PMR }\end{array}$ & $\begin{array}{l}1.58 \\
1.88 \\
4.76\end{array}$ & $\begin{array}{r}0.51-3.69^{\mathrm{b}} \\
1.18-2.85^{\mathrm{b}} \\
0.12-26.50^{\mathrm{b}}\end{array}$ \\
\hline Roseo, 1995 (27) & Turin & $1981-1989$ & $\begin{array}{l}\text { Teachers and professors } \\
\text { Teachers and professors }\end{array}$ & $\begin{array}{l}\text { All } \\
\text { All }\end{array}$ & $\begin{array}{l}\text { Male } \\
\text { Female }\end{array}$ & 2 & $\begin{array}{l}\text { SMR } \\
\text { SMR }\end{array}$ & $\begin{array}{r}0 \\
1.82\end{array}$ & $0.22-6.57^{\mathrm{b}}$ \\
\hline Roseo, 1995 (27) & Italy & $1981-1982$ & $\begin{array}{l}\text { Teachers and professors } \\
\text { Teachers and professors }\end{array}$ & $\begin{array}{l}18-64 \\
18-64\end{array}$ & $\begin{array}{l}\text { Male } \\
\text { Female }\end{array}$ & $\begin{array}{l}2 \\
4\end{array}$ & $\begin{array}{l}\text { MOR } \\
\text { MOR }\end{array}$ & $\begin{array}{r}3.61 \\
12.52\end{array}$ & $\begin{array}{l}. \cdot \\
. .\end{array}$ \\
\hline Pukkala, 1995 (28) & Finland & $1971-1985$ & $\begin{array}{l}\text { All teachers } \\
\text { All teachers }\end{array}$ & $\begin{array}{l}35-64 \\
35-64\end{array}$ & $\begin{array}{l}\text { Male } \\
\text { Female }\end{array}$ & $\begin{array}{l}6 \\
9\end{array}$ & $\begin{array}{l}\text { SIR } \\
\text { SIR }\end{array}$ & $\begin{array}{l}0.75 \\
1.12\end{array}$ & $\begin{array}{l}0.28-1.63 \\
0.51-2.13\end{array}$ \\
\hline King et al, 1994 (31) & British Columbia & $1950-1984$ & $\begin{array}{l}\text { School teachers } \\
\text { School teachers }\end{array}$ & $\begin{array}{l}\geq 20 \\
\geq 20\end{array}$ & $\begin{array}{l}\text { Male } \\
\text { Female }\end{array}$ & $\begin{array}{r}6 \\
15\end{array}$ & $\begin{array}{l}\text { PMR } \\
\text { PMR }\end{array}$ & $\begin{array}{l}1.02 \\
1.76\end{array}$ & $\begin{array}{l}0.37-2.23 \\
0.98-2.91\end{array}$ \\
\hline
\end{tabular}

a Approximate summary estimates of relative risk: studies based on incidence or mortality rates: number of cases $28, \mathrm{RR} 1.04,95 \% \mathrm{Cl} 0.69-1.51$; studies based on proportional mortality, mortality odds ratios or proportional cancer incidences: number of cases $725, \mathrm{RR} 1.58,95 \% \mathrm{Cl} 1.47$ - 1.70 . "Calculated by us.

c Whites.

d Blacks.

e Excludes reference 20 because of overlap by reference 22 .

\section{Overall pattern of findings}

The study that most consistently suggests high risks of leukemia and related diseases among teachers is the latest national analysis of occupational mortality for England and Wales (1). However, this analysis was based on PMR values, which will tend to overestimate the risk of teachers. In addition, less weight can be given to its findings in so far as they were the stimulus for the current review.

Several other investigations have suggested elevated risks of leukemia, but again they have mostly been based on proportional mortality or mortality odds ratios. Increased SMR values were found for leukemia among female school teachers in the Registrar General's analysis of occupational mortality for 1970-1972 (10) and for myeloid leukemia among male nonuniversity teachers in the corresponding analysis for 1979-1980 and 19821983 (11). In addition, a high incidence of leukemia was recorded among teachers in the Portland Vancouver metropolitan area in a comparison with the general population (19). Against these findings, however, there was no materially increased risk in the earlier SMR analyses by the Registrar General $(8,9)$, in the follow-up study of US veterans (17), or in the national analysis of occupational mortality for Finland during 1971-1985 (28).

Overall, there was no significant excess of leukemia among teachers in investigations that analyzed incidence or mortality rates as opposed to proportions (RR 1.06, 95\% CI 0.94-1.19). The corresponding risk estimate for lymphatic leukemia was higher (RR $1.77,95 \%$ CI 1.22 2.47 ), but it was derived from only 2 studies and is likely to have been inflated by biases in reporting.

Some studies have suggested an elevated rate of lymphoma (both Hodgkin's disease and non-Hodgkin's lymphoma) for teaching professions, but, as with leukemia, they have mostly been proportional mortality analyses or 
case-referent studies based on death certificates. Therefore, their risk estimates are likely to have been exaggerated by low mortality from other causes. In the studies that examined incidence or mortality rates there was no overall excess of Hodgkin's disease, but the summary risk estimate for non-Hodgkin's lymphoma was significantly increased (RR $1.36,95 \%$ CI 1.13-1.62). This finding is suspicious, but it may have been a product of publication and reporting bias and cannot be regarded as strong evidence of a hazard.

Almost all of the published data on multiple myeloma in teachers come from proportional analyses, and, while many of them suggest an increased risk, the finding may simply reflect low death rates from other diseases.

\section{Concluding remarks}

In balance, there is no compelling epidemiologic evidence for an occupational hazard of leukemia or related diseases for teachers, and the elevated PMR values found in England and Wales during 1979-1980 and 19821990 could well be attributable to a combination of low overall mortality among teachers and chance. If the incidence of lymphatic and hematopoietic cancer is increased, then the elevation of risk is probably for nonHodgkin's lymphoma and small in absolute terms.

\section{Acknowledgments}

This work was supported by a contract from the UK Health and Safety Executive.

\section{References}

1. Coggon D, Inskip H, Winter P, Pannett B. Occupational mortality by cause of death. In: Drever F, editor. Occupational health decennial supplement. London: Her Majesty's Stationery Office, 1995:62-76.

2. Sullivan AK. Classification, pathogenesis, and etiology of neoplastic diseases of the hematopoietic system. In: Lee GR, Bithell TC, Foerster J, Athens JW, Lukens JN, editors. Wintrobe's clinical hematology, vol 2. Philadelphia (PA): Lea and Febiger, 1993:1725-91.

3. Biggar RJ, Rabkin CS. The epidemiology of AIDS-related neoplasms. Hematol Oncol Clin North Am 1996;10:9971010.

4. Flinn IW, Ambinder RF. AIDS primary central nervous system lymphoma. Curr Opin Oncol 1996;8:373-6.

5. Kinlen LJ, Clarke K, Hudson C. Evidence from population mixing in British new towns 1946-85 of an infective basis for childhood leukaemia. Lancet 1990;336:577-82.

6. Kinlen LJ, Dickson M, Stiller CA. Childhood leukaemia and non-Hodgkin's lymphoma near large rural construction sites, with a comparison with Sellafield nuclear site. BMJ
$1995 ; 310: 763-8$.

7. Hodgson JT, Jones JR, Elliott RC, Osman J. Self-reported work-related illness. Sudbury: HSE Books, 1993.

8. Registrar General. Decemnial supplement England and Wales 1951 occupational mortality. London: Her Majesty's Stationery Office, 1958.

9. Registrar General. Decennial supplement England and Wales 1961 occupational mortality tables. London: Her Majesty's Stationery Office, 1971.

10. Office of Population Censuses and Surveys. Occupational mortality 1970-72. London: Her Majesty's Stationery Office, 1978.

11. Office of Population Censuses and Surveys. Occupational mortality 1979-80 and 1982-83. London: Her Majesty's Stationery Office, 1986.

12. Roman E, Carpenter L. Cancer incidence in England 198187. In: Drever F, editor. Occupational health decennial supplement. London: Her Majesty's Stationery Office, 1995:77102.

13. Guralnick L. Mortality by occupation and cause of death among men 20 to 64 years of age: United States, 1950. Washington (DC): US Department of Health, Education, and Welfare, 1963. Vital statistics - special reports, vol 53, no 3.

14. Milham S. Occupational mortality in Washington State 1950-89. Cincinnati (OH): National Institute for Occupational Safety and Health, 1997.

15. Milham S. Hodgkin's disease as an occupational disease of school teachers. N Engl J Med 1974;290:1329.

16. Petersen GR, Milham S. Occupational mortality in the state of California 1959-1961. Cincinnati (OH): National Institute for Occupational Safety and Health, 1980.

17. Hrubec Z, Blair AE, Rorot E, Vaught J. Mortality risks by occupation among US veterans of known smoking status. Bethesda (MD): USA Department of Health and Human Services, 1992. NIH publication, no 92-3407.

18. Dubrow R, Wegman DH. Cancer and occupation in Massachusetts: a death certificate study. Am J Ind Med 1984:6:207-30.

19. Morton W, Marjanovic D. Leukemia incidence by occupation in the Portland-Vancouver metropolitan area. Am J Ind Med 1984;6:185-205.

20. Burnett MS, Maurer J, Dosemeci M. Mortality by occupation, industry and cause of death: 24 reporting states, 1984-1988. Cincinnati (OH): US Department of Health and Human Services, 1997.

21. Figgs LW, Dosemeci M, Blair A. United States non-Hodgkin's lymphoma surveillance by occupation 1984-1989: a 24 state death certificate study. Am J Ind Med 1995;27:81735.

22. Figgs LW, Dosemeci M, Blair A. Risk of multiple myeloma by occupation and industry among men and women: a 24 state death certificate study. J Occup Med 1994;36:1210-21.

23. Rosenman KD. Causes of mortality in primary and secondary school teachers. Am J Ind Med 1994;25:749 _ 58.

24. Dewar RF. Proportional analysis of associations between elementary and secondary school teachers and deaths from malignant neoplasms using 1983 and 1984 Pennsylvania death data. Harrisburg (PA): Department of Health Pennsylvania, 1986.

25. Grufferman S, Duong T, Cole P. Brief communication: occupation and Hodgkin's disease. JNCI 1976;57:1193-5.

26. Olsen JH, Jensen OM. Occupation and risk of cancer in Denmark: an analysis of 93810 cancer cases 1970-1979. Scand J Work Environ Health 1987;13 suppl 1:1—91. 
27. Roseo G, editor. Mortalita per professioni in Italia negli anni ' 80 [Mortality by occupation in Italy in 1980]. Rome: Istituto Poligrafico e Zecca dello Stato, 1995.

28. Pukkala E. Cancer risk by social class and occupation: a survey of 109,000 cancer cases among Finns of working age. Basel: Karger, 1995.

29. Minder CE, Beer-Porizek V. Cancer mortality of Swiss men by occupation, 1979-1982. Scand J Work Environ Health 1992;18 suppl 3:1-27.

30. Linet MS, Malker HSR, McLaughlin JK, Weiner JA, Blot WJ, Ericsson JL, et al. Non-Hodgkin's lymphoma and occupation in Sweden: a registry based analysis. Br J Ind Med 1993;50:79-84.

31. King AS, Threlfall WJ, Band PR, Gallagher RP. Mortality among female registered nurses and school teachers in British Columbia. Am J Ind Med 1994:26:126-32.

32. Heasman MA, Liddell FDK, Reid DD. The accuracy of occupational vital statistics. Br J Ind Med 1958;15:141-6.

33. Kinlen LJ, Rogot E. Leukaemia and smoking habits among
United States veterans. BMJ 1988;297:657-6-9.

34. Mills PK, Newell GR, Beeson WL, Fraser GE, Phillips RL History of cigarette smoking and risk of leukaemia and myeloma: results from the Adventist health study. JNCI 1990;82:1832-6.

35. Garfinkel L, Boffetta P. Association between smoking and leukaemia in two American Cancer Society prospective studies. Cancer 1990;65:2356-60.

36. Linet MS, McLaughlin JK, Hsing AW, Wacholder S, CoChien HT, Schuman LM, et al. Cigarette smoking and leukaemia: results from the Lutheran Brotherhood Cohort Study. Cancer Causes Control 1991;2:413-7.

37. Doll R, Peto R. Mortality in relation to smoking: 20 years observations on male British doctors. BMJ 1976;2:1525-36.

38. Chambers R, Belcher J. Comparison of the health and lifestyle of general practitioners and teachers. $\mathrm{Br} \mathrm{J}$ Gen $\mathrm{Pr}$ 1993;43:378-82.

Received for publication: 30 December 1997 